Терапевтична стоматологія

УдК 616.314-083+613.842+616.313-008.6

DOI 10.11603/2311-9624.2018.2.8934

(C) Т. І. Пупін, О. І. Кардашевська

Львівський національний медичний університет імені Данила Галицького

\title{
Оцінка ефективності лікування хронічного катарального гінгівіту в працівників птахофабрик за даними клінічних спостережень та параклінічних індексів
}

\begin{abstract}
Резюме. Результати досліджень захворювань пародонта показують, що виникнення патологічних змін у зубоутримувальних тканинах відбуваються при зміні загального стану організму, внаслідок дії низки ендогенних та екзогенних чинників, які визначають підходи до лікування і профілактики цих захворювань. Незважаючи на автоматизацію і механізацію птахоферм, все більший відсоток працівників птахофабрик зазнає впливу несприятливих виробничих факторів, що призводить до професійних захворювань, зокрема захворювань пародонта.

Мета дослідження - оцінити ефективність розробленої схеми лікування хронічного катарального гінгівіту в працівників птахофабрик за даними клінічних спостережень та параклінічних індексів.

Матеріали і методи. Для оцінки ефективності лікування хронічного катарального гінгівіту (ХКГ) під спостереженням перебувало 39 працівників птахофабрик, яких поділили на 2 рівноцінні групи: основну (20 осіб), у якій лікування проводили згідно зі схемою, яку ми розробили, та контрольну (19 осіб), де хворих лікували за загальноприйнятою методикою відповідно до Протоколів Мо3 України щодо надання медичної допомоги за спеціальністю «Терапевтична стоматологія».

Результати досліджень та їх обговорення. У працівників птахофабрик, хворих на ХКГ, через місяць після лікування значення індексу ПІ в основній групі становило $(0,45 \pm 0,03)$ бала, значення індексу PMA зменшилось у 2 рази: $(12,28 \pm 2,28)$ \%, значення індексу OHI-S відповідало задовільній гігієні: $(0,98 \pm 0,02)$ бала. Через 6 місяців після лікування у пацієнтів основної групи досліджували стабілізацію пародонтального індексу ПІ зі значенням $(0,45 \pm 0,04)$ бала, зниження індексу PМА до $(11,79 \pm 2,23)$ та індексу OHI-S до $(1,08 \pm 0,01)$ бала. Через 12-18 місяців значення індексу ПІ в основній групі дорівнювало $(0,63 \pm 0,23)$ бала, показник індексу РМА знизився до $(14,37 \pm 2,26) \%$. Стан гігієни порожнини рота за індексом OHI-S в основній групі оцінювали як задовільний зі значенням $(1,28 \pm 0,04)$ бала.

Висновки. В основній групі на всіх етапах клінічно спостерігали ліквідацію запального процесу в яснах, що підтверджувалось зниженням пародонтальних індексів РМА до $(11,79 \pm 2,23) \%$, ПІ - до $(14,37 \pm 2,26) \%$, зменшенням показника гігієнічного індексу OHI-S до $(1,08 \pm 0,01)$ бала. Таким чином, запропонована лікувальна модель давала змогу покращити ефективність та скоротити терміни лікування хронічного катарального гінгівіту в працівників птахофабрик.
\end{abstract}

Ключові слова: працівники птахофабрик; хронічний катаральний гінгівіт; параклінічні індекси; лікування.

\section{(с). И. Пупин, О. И. Кардашевская}

Львовский национальный медицинский университет имени Данила Галицкого

\section{Оценка эффективности лечения хронического катарального гингивита у работников птицефабрик по данным клинических наблюдений и параклинических индексов}

Резюме. Результаты исследований заболеваний пародонта показывают, что возникновение патологических изменений в зубоудерживающих тканях происходят при изменении общего состояния организма, в результате действия ряда эндогенных и экзогенных факторов, определяющих подходы к лечению и профилактике этих заболеваний. Несмотря на автоматизацию и механизацию птицеферм, все больший процент работников птицефабрик подвергается воздействию неблагоприятных производственных факторов, что приводит к профессиональным заболеваниям, в частности заболеваний пародонта.

Цель исследования - оценить эффективность разработанной схемы лечения хронического катарального гингивита у работников птицефабрик по данным клинических наблюдений и параклинических индексов. 
Материалы и методы. Для оценки эффективности лечения хронического катарального гингивита (ХКГ) под наблюдением находилось 39 работников птицефабрик, которых распределили на 2 равноценные группы: основную (20 человек), в которой лечение проводилось, согласно разработанной нами схемы, и контрольную (19 человек), где больных лечили по общепринятой методике согласно Протоколов МЗ Украины оказания медицинской помощи по специальности «Терапевтическая стоматология».

Результаты исследований и их обсуждение. У работников птицефабрик, больных ХКГ, через месяц после лечения значение индекса ПИ в основной группе составило $(0,45 \pm 0,03)$ балла, значение индекса PMA уменьшилось в 2 раза: $(12,28 \pm 2,28) \%$, значение индекса OHI-S соответствовало удовлетворительной гигиене: $(0,98 \pm 0,02)$ балла. Через 6 месяцев после лечения у пациентов основной группы исследовали стабилизации пародонтального индекса Пи со значением $(0,45 \pm 0,04)$ балла, снижение индекса PMA до $(11,79 \pm 2,23)$ и индекса OHI-S до $(1,08 \pm 0,01)$ балла. Через $12-18$ месяцев значение индекса Пи в основной группе равнялось $(0,63 \pm 0,23)$ балла, показатель индекса РМА снизился до $(14,37 \pm 2,26) \%$. Состояние гигиены полости рта согласно индекса OHI-S в основной группе оценивалось как удовлетворительное со значением $(1,28 \pm 0,04)$ балла.

Выводы. В основной группе на всех этапах клинически наблюдали ликвидацию воспалительного процесса в деснах, что подтверждалось снижением пародонтальных индексов РМА до $(11,79 \pm 2,23)$ \%, ПИ до $(14,37 \pm 2,26) \%$, уменьшением показателя гигиенического индекса OHI-S до $(1,08 \pm 0,01)$ балла. Таким образом, предложенная лечебная модель позволила повысить эффективность и сократить сроки лечения хронического катарального гингивита у работников птицефабрик.

Ключевые слова: работники птицефабрик; хронический катаральный гингивит; параклинические индексы; лечение.

\author{
CT. I. Pupin, O. I. Kardashevska \\ Danylo Halytskyi Lviv National Medical University
}

\title{
Evaluation efficiency of treatment of chronic catarrhal gingivitis from poultry factory workers according to clinical observations and paraclinical indices
}

Summary. The research of periodontal diseases provides the basis for a generalized conclusion that the occurrence of pathological changes in the teeth-containing tissues occurs when the general state of the organism changes, due to the action of a number of endogenous and exogenous factors that determine the approaches to the treatment and prevention of these diseases. Despite the automation and mechanization of poultry farms, an increasing percentage of poultry workers are exposed to adverse productive factors, which lead to occupational diseases, in particular periodontal diseases.

The aim of the study - to evaluate the effectiveness of the developed scheme of treatment of chronic catarrhal gingivitis in poultry factory workers according to clinical observations and paraclinical indices.

Materials and Methods. To evaluate the effectiveness of the treatment of chronic catarrhal gingivitis (CCG), there were 39 employees of poultry farms, who were divided into 2 equal groups: the main (20 persons), in which treatment was performed according to the scheme we developed and control (19 people), where patients were treated for according to the "Protocols of the Ministry of Health of Ukraine" the provision of medical care in the specialty "Therapeutic Dentistry".

Results and Discussion. In case of poultry factory workers, patients with CCG, 1 month after treatment, the index of PI in the main group was $(0.45 \pm 0.03)$ points, the value of the index of PMA decreased by 2 times: $(12.28 \pm 2.28) \%$, the value of the index OHI- S corresponded to satisfactory hygiene: $(0.98 \pm 0.02)$ points. Six months after treatment, patients in the main group who tested for stabilization of the periodontal index of PI with a value of $(0.45 \pm 0.04)$ points, a decrease in the PMA index to $(11.79 \pm 2.23)$ and an OHI-S index of $(1.08 \pm 0.01)$ score. In $12-18$ months, the value of the index of PI in the main group was $(0.63 \pm 0.23)$ points, the index PMA fell to $(14.37 \pm 2.26) \%$. The condition of oral hygiene according to the OHI-S index in the main group was assessed as "satisfactory" with a value of (1.28 \pm 0.04$)$ points.

Conclusions. In the main group, the elimination of the inflammatory process in the gums was clinically observed at all stages, which was confirmed by a decrease in the periodontal indices PMA up to (11.79 \pm 2.23$) \%$, PI up to $(14.37 \pm 2.26) \%$, a decrease in the index of the hygiene index OHI-S to (1.08 \pm 0.01$)$ points. Thus, the proposed therapeutic model allowed to increase the efficiency and reduce the duration of treatment of chronic catarrhal gingivitis in workers of poultry farms.

Key words: workers of poultry farms; chronic catarrhal gingivitis; paraclinical indices; treatment. 
Вступ. Захворювання пародонта становлять важливу медико-соціальну проблему у зв’язку з їх високою поширеністю, схильністю до прогресування та формуванням комплексу патологічних змін, що призводять до порушень основних функцій пародонта та зубощелепної системи [3, 5, 10].

Результати досліджень захворювань пародонта підтверджують, що виникнення патологічних змін у зубоутримувальних тканинах відбуваються при зміні загального стану організму, внаслідок дії низки ендогенних та екзогенних чинників, які визначають підходи до лікування і профілактики цих захворювань. Підтвердженням тісного взаємозв'язку захворювань пародонта $з$ реакцією його тканин і макроорганізму на фактори зовнішнього середовища $є$ висока частота захворювань у забруднених регіонах. У зв'язку з цим, вивчення несприятливих чинників довкілля на стан зубоутримувальних тканин належить до пріоритетних наукових напрямків [1, 7, 8, 13].

Однією з галузей агропромислового комплексу України, що активно розвивається останнім часом, є птахівництво. Незважаючи на автоматизацію і механізацію птахоферм, все більший відсоток працівників зазнає впливу несприятливих виробничих факторів: запиленість, мікроклімат, загазованість (аміак, сірководень, високі концентрації вуглекислоти, формальдегід), бактеріальна і грибкова забрудненість повітря робочої зони, виробничий шум, висока вологість, що призводять до виникнення професійних захворювань у працівників птахофабрик, зокрема захворювань тканин пародонта [11].

Метою дослідження було оцінити ефективність розробленої схеми лікування ХКГ у працівників птахофабрик за даними параклінічних індексів у найближчі та віддалені терміни.

Матеріали і методи. Для оцінки ефективності лікування ХКГ під спостереженням перебувало 39 працівників птахофабрик, яких поділили на 2 рівноцінні групи: основну (20 осіб), у якій лікування проводилося згідно зі схемою, яку ми розробили, та контрольну (19 осіб), де хворих лікували за загальноприйнятою методикою відповідно до Протоколів МO3 України щодо надання медичної допомоги за спеціальністю «Терапевтична стоматологія». Клінічно оцінювали ефективність лікування за критеріями "нормалізація», «покращення», «без змін». Оцінку найближчих результатів лікування проводили візуально, з урахуванням зміни клінічних симптомів та за допомогою пародонтальних та гігієнічного індексів (через 1 місяць). Ефективність лікування у віддалені терміни спостереження фіксували через 6 місяців, та 12-18 місяців після лікування. Пародонтологічний статус оцінювали за індексами РМА, ПI. Гігієну порожнини рота визначали згідно з індексом OHI-S [5, 6].

Лікування хронічного катарального гінгівіту в основній групі складалося з декількох етапів. Перший етап включав навчання правил гігієни порожнини рота 3 наступним контролем за допомогою еритрозину червоного, призначення індивідуального гігієнічного режиму порожнини рота, індивідуальний підбір зубної пасти і щітки. Другий етап включав професійну гігієну порожнини рота: після антисептичної обробки хлоргексидином (0,2 \% розчин) видаляли над’ясенні й під’ясенні зубні відкладення ультразвуковим скейлером із наступним поліруванням поверхні коронок і коренів зубів [9, 12]; усували місцеві фактори, що сприяють накопиченню й активації дії мікробного фактора (пломбування каріозних порожнин, усунення дефектів пломб, відновлення міжзубних контактних пунктів; проводили функціональне вибіркове пришліфування, ліквідацію супраконтактів для виключення травматичної оклюзії, що підтримують запалення; шинували рухомі зуби). Місцева протизапальна терапія включала аплікації на ясна гелю «Solcoseryl - dental adhesive», депротеїнізованого діалізату, отриманого 3 крові здорових молочних телят, що посилює проліферацію, регенерацію ушкоджених клітин, стимулює ангіогенез у регенерованій тканині, стимулює синтез колагену. «Solcoseryl - dental adhesive» при нанесенні на ясна утворює лікувальну пов'язку, що оберігає слизову оболонку від механічних та хімічних пошкоджень, а головне, забезпечує пролонгований ефект дії препарату. Також для місцевої протизапальної терапії пацієнтам призначали полоскання та ротові ванночки мінеральною водою «Плосківська», наявність ортоборної кислоти, яка надає виражених бактерицидних властивостей. Для зменшення проникливості та ламкості капілярів пацієнтам рекомендували приймати Аскорутин (по 0,5 г 3 рази на добу).

Результати досліджень та їх обговорення. У працівників птахофабрик із ХГК у найближчі терміни спостереження (через місяць після лікування) «нормалізацію» уражених 
тканин було діагностовано у 12 пацієнтів $(60,00 \pm 10,95) \%$ основної групи та у 5 досліджуваних контрольної групи $(26,31 \pm 9,35) \%$, $\mathrm{p}<0,01$. У 8 осіб $(40,00 \pm 10,95) \%$ основної групи та у 8 осіб $(42,11 \pm 11,33) \%$ групи контролю фіксували «покращення» стану тканин пародонта, $p>0,05$. Збереження клінічних симптомів хронічного гінгівіту спостерігали лише у 6 пацієнтів контрольної групи $(31,58 \pm 10,66) \%$. Під час проведення комплексної терапії у хворих із «нормалізацією» стану тканин пародонта зникали кровоточивість, болючість та неприємні відчуття у яснах, значно зменшувався набряк міжзубних ясенних сосочків, вони чітко контурувались, ставали щільними; ясна набували блідо-рожевого кольору, що підтверджується результатами визначення пародонтальних та гігієнічного індексів. У хворих контрольної групи гінгівіт був резистентним до лікувальних заходів і позитивний результат не завжди спостерігався після повного курсу лікування, який тривав на два-три відвідування довше, ніж в основній групі. На кращі результати лікування в основній групі вказують показники індексних оцінок стану тканин пародонта.

У найближчі терміни спостереження було зафіксовано зниження індексних значень як у основній, так і в контрольній групах. Через місяць після лікування значення індексу ПІ в основній групі становило $(0,45 \pm 0,03)$ бала, $\mathrm{p}<0,01$, i було у 1,6 раза меншим, порівняно 3 групою контролю, $(0,73 \pm 0,06)$ бала, $p<0,01$. Значення індексу PМА в основній групі зменшилось у 2 рази через місяць після лікування: $(12,28 \pm 2,28) \%, \mathrm{p}<0,05$ проти $(15,71 \pm 2,20) \%$ групи контролю, $p>0,05$. Через місяць після лікування значення індексу OHI-S в обох групах відповідало задовільній гігієні: $(0,98 \pm 0,02)$ бала та $(1,29 \pm 0,03)$ бала відповідно, $\mathrm{p}<0,01$. Через 6 місяців після проведеного лікування у працівників птахофабрик із ХГК «нормалізацію» уражених тканин було діагностовано у 14 пацієнтів $(70,00 \pm 10,25) \%$ основної групи та у 4 осіб контрольної групи $(21,05 \pm 9,35) \%, \mathrm{p}<0,01$. В 6 осіб $(30,00 \pm 10,25) \%$ основної та у 5 осіб $(26,31 \pm 10,10) \%$ групи контролю виявили «покращення» стану тканин пародонта, $\mathrm{p}>0,05$. Клінічний стан тканин пародонта підтвердили дані параклінічних індексів. У пацієнтів основної групи через 6 місяців після лікування досліджували стабілізацію пародонтального індексу ПІ зі значенням $(0,45 \pm 0,04)$ бала, $\mathrm{p}<0,01$, що було у 1,6 раза менше від даних групи контролю: $(0,72 \pm 0,26)$ бала, $\mathrm{p}<0,01$. Значення індексу РМА знизилось до $(11,79 \pm 2,23) \%$ проти $(19,24 \pm 3,28)$ \% групи контролю, р>0,05. Зменшення індексу OHI-S в основній групі - до $(1,08 \pm 0,01)$ бала, $\mathrm{p}<0,01$, що було у 1,6 раза iнтенсивніше ніж групи контролю: $(1,74 \pm 0,02)$ бала, $\mathrm{p}<0,01$.

У віддалені терміни спостереження, через 12-18 місяців «нормалізація» стану тканин пародонта була у 16 працівників із ХКГ основної групи $(80,00 \pm 8,94) \%$, що у 5 разів перевищувало даний показник у групі контролю $(15,79 \pm 8,36) \%, p<0,01$. «Покращення» стану тканин пародонта констатували тільки у 4 пацієнтів основної групи $(20,00 \pm 8,94) \%$. Неефективним виявилось проведене лікування у 16 осіб $(84,21 \pm 8,36) \%$ контрольної групи. Через 12-18 місяців значення індексу ПІ в основній групі становило $(0,63 \pm 0,23)$ бала, $\mathrm{p}<0,01$ проти $(0,89 \pm 0,44)$ бала групи контролю, $\mathrm{p}<0,01$. Показник індексу РМА в основній групі знизився до $(14,37 \pm 2,26) \%, p<0,05$, i був у 1,7 раза меншим, ніж у групі контролю, - $(24,89 \pm 3,18)$ $\%, \mathrm{p}<0,05$. Стан гігієни порожнини рота за індексом OHI-S в основній групі оцінювали як «задовільний» із значенням $(1,28 \pm 0,04)$ бала, $\mathrm{p}<0,01$. Проте у групі контролю через $12-18$ місяців після лікування гігієна порожнини рота виявилась "незадовільною». Загалом, у віддалені терміни після лікування у пацієнтів контрольної групи значення параклінічних індексів перевищували вихідні дані, які ми розцінювали як погіршення стану тканин пародонта унаслідок недостатньої ефективності проведених лікувальних заходів.

Висновки. В основній групі на всіх етапах клінічно спостерігали зникнення кровоточивості, болючості та неприємних відчуттів у яснах, зменшення набряку міжзубних ясенних сосочків, що вказувало на ліквідацію запального процесу. Ефективність лікування в основній групі клінічно підтверджена зниженням пародонтальних індексів: РМА до $(11,79 \pm 2,23) \%$, ПІ - до $(14,37 \pm 2,26) \%, \mathrm{p}<0,05$; зменшенням значення гігієнічного індексу OHI-S до $(1,08 \pm 0,01)$ бала, $\mathrm{p}<0,01$. У хворих контрольної групи гінгівіт був резистентним до лікувальних заходів i позитивний результат не завжди мав місце після повного курсу лікування, який тривав на два-три відвідування довше, ніж в основній групі, що було підтверджено даними параклінічних індексів. Таким чином, запропонована лікувальна модель давала змогу покращити ефективність та скоротити терміни лікування 
хронічного катарального гінгівіту в працівників птахофабрик.

Перспективи подальших досліджень. У фахових літературних джерелах ми знайшли обмежену інформацію про захворювання па- родонта у працівників птахофабрик, тому перспективою подальших досліджень стане розробка алгоритмів лікування та профілактики генералізованого пародонтиту в даного контингенту хворих.

\section{Список літератури}

1. Бабов Є. Д. Стоматологічна захворюваність працівників аміачного виробництва / $€$. Д. Бабов, I. О. Михайленко // Вісн. стоматології. - 2008. - № 1. - C. 22-23.

2. Басанец А. В. Проблемы профессиональной патологии в Украине и пути их решения на современном этапе / А. В. Басанец, О. П. Краснюк, I. П. Лубянова // Гігієнічна наука та профілактика на рубежі століть : матеріали XIV з'їзду гігієністів України. Дніпропетровськ, 2003. - С. 38-40.

3. Белоклицкая Г. Ф. Современный взгляд на классификацию болезней пародонта / Г. Ф. Белоклицкая // Современная стоматология. - 2007. - № 3(39). C. 59-64.

4. Бодиенкова Г. М. Актуальные вопросы профессиональной аллергопатологии в современный период / Г. М. Бодиенкова, В. С. Рукавишников, О. В. Ушакова // Медицина труда и промышленная экология. - 2010. - № 1. - С. 11-14.

5. Болезни пародонта / А. С. Григорьян, А. И. Грудя нов, Н. А. Рябухина, О. А. Фролова. - М. : Медицинское инф. агентство, 2004. - 320 с.

6. Борисенко А. В. Индексная оценка интенсивности воспалительных и деструктивных изменений в тканях пародонта при генерализованном пародонтите / А. В. Борисенко, А. Г. Ткаченко // Современная стоматология. - 2005. - № 1. - С. 64-65.

\section{References}

1. Babov, Ye.D. (2008). Stomatolohichna zakhvoriuvanist pratsivnykiv amiachnoho vyrobnytstva [Dental morbidity of workers in ammonia production]. Visnyk stomatolohii - Herald of Dentistry, 1 [in Ukrainian].

2. Basanets, A.V., Krasnyuk, O.P., \& Lubyanova, I.P. (2003). Problemy professionalnoy patologii v Ukraine i puti ikh resheniya na sovremennom etape [Problems of professional pathology in Ukraine and ways of their solution at the present stage]. Hihiienichna nauka ta profilaktyka na rubezhi stolit: materialy XIV zizdu hihiienistiv Ukrainy - Hygienic science and prevention at the turn of the century: Materials of the XIV Congress of Ukrainian Hygienists. Dnipropetrovsk [in Russian]. 3. Beloklitskaya, G.F. (2007). Sovremennyy vzglyad na klassifikatsiyu bolezney parodonta [Modern view on the classification of periodontal diseases]. Sovremennaya stomatologiya - Modern Dentistry, 3 (39), 59-64 [in Russian]. 4. Bodienkova, G.M., Rukavishnikov, V.S., \& Ushakova O.V., (2010). Aktualnye voprosy professionalnoy allergopatologii v sovremennyy period [Actual issues of occupational allergopathology in the modern period]. Meditsina truda $i$ promyishlennaya ekologiya - Occupational Medicine and Industrial Ecology, 1, 11-14 [in Russian].
7. Бочковская О. О. Исследование потребности в стоматологической помощи у различных групп населения / О. О. Бочковская // Клиническая стоматология. - 2006. - № 1 (37). - С. 58-62.

8. Вейсгейм Л. Д. Состояние вопроса о влиянии соматических заболеваний на клинику и лечение пародонтитов / Л. Д. Вейсгейм, Е. В. Люмкис // Новое в стоматологии. - 2004. - № 6. - С. 75-76.

9. Грудянов А. И. Влияние поддесневых гидроорошений с помощью ирригатора Water Pik на микробный состав пародонтальных карманов / А. И. Грудянов, Н. А. Дмитриева, Н. Н. Домашева // Пародонтология. - 2009.- № 1. - С. 19-22.

10. Заболотний Т. Д. Запальні захворювання пародонта / Т. Д. Заболотний, А.В. Борисенко. - Львів : ГалДент, 2013. - 205 с.

11. Прокудіна Н. О. Професійні захворювання робітників у птахівництві, що викликані патогенними грибами та умовно-патогенною мікрофлорою / Н. О. Прокудіна // Сучасна вет. медицина. - 2013. № 1. - С. 22-25 ; № 2. - С. 30-33.

12. Улитовский С. Б. Гигиена полости рта после проведения профессиональной гигиены / С. Б. Улитовский // Новое в стоматологии. - 2006. - № 5. - С. 94-97. 13. Casamassimo P. Relationships between oral and systemic health / P. Casamassino // Pediatric Clinics of North America. - 2003. - Vol. 47, No. 5. - P. 1149-1157.

5. Grigoryan, A.S., Grudyanov, A.I., Ryabukhina, N.A., \& Frolova, O.A. (2004). Bolezni parodonta [Periodontal diseases]. Moscow: Meditsinskoe inf. agentstvo [in Russian].

6. Borisenko, A.V., \& Tkachenko, A.G. (2005). Indeksnaya otsenka intensivnosti vospalitelnykh i destruktivnykh izmeneniy v tkanyakh parodonta pri generalizovannom parodontite [Index evaluation of the intensity of inflammatory and destructive changes in periodontal tissues with generalized periodontitis]. Sovremennaya stomatologiya - Modern Dentistry, 1, 64-65 [in Russian]. 7. Bochkovskaya, O.O. (2006). Issledovanie potrebnosti $\mathrm{v}$ stomatologicheskoy pomoshchi $\mathrm{u}$ razlichnykh grup naseleniya [Research of the need for dental care in different population groups]. Klinicheskaya stomatologiya - Clinical Dentistry, 1 (37), 58-62 [in Russian].

8. Veysgeym, L.D., \& Lyumkis, E.V. (2004). Sostoyanie voprosa o vliyanii somaticheskikh zabolevaniy na kliniku i lechenie parodontitov [The state of the issue of the influence of somatic diseases on the clinic and the treatment of periodontitis]. Novoe $v$ stomatologii - New in the Dentistry, 6, 75-76 [in Russian].

9. Grudyanov, A.I., Dmitrieva, H.A., \& Domasheva H.H., 
(2009). Vliyanie poddesnevykh gidroorosheniy s pomoshchyu irrigatora Water Pik na mikrobnyy sostav parodontalnykh karmanov [Influence of subgingival hydrosurgeons with the help of Irrigator Water Pik on microbial composition of periodontal pockets]. Parodontologiya - Periodontology, 1 [in Russian].

10. Zabolotnyi, T.D., \& Borysenko, O.V. (2013). Zapalni zakhvoriuvannia parodonta [Inflammatory periodontal disease]. Lviv: GalDent [in Ukrainian].

11. Prokudina, N.O. (2013). Profesiini zakhvoriuvannia robitnykiv u ptakhivnytstvi, shcho vyklykani patohennymy grybamy ta umovno-patohennoiu mikrofloroiu [Occupational diseases of workers in poultry farming caused by pathogenic fungi and opportunistic microflora]. Suchasna vet. medytsyna - Modern Veterinary Medicine, 1, 22-25 (2), 30-33 [in Ukrainian].

12. Ulitovskiy, S.B. (2006). Gigiyena polosti rta posle provedeniya professionalnoy gigieny [Hygiene of the oral cavity after professional hygiene]. Novoe $v$ stomatologii - New in Dentistry, 5, 94-97 [in Russian] 13. Casamassimo, P. (2003). Relationships between oral and systemic health. Pediatric Clinics of North America, 47 (5), 1149-1157.

Отримано 02.04.18 